\title{
SEARCH AND SEIZURE IN SCHOOLS: A COMPARISON OF HISTORICAL JEWISH LEGAL SOURCES AND CONTEMPORARY UNITED STATES LAW
}

\section{Rabbi Moshe A. Bleich, MSW \& Daniel Pollack, MSW, JD**}

It is inconceivable that a thousand years ago a rabbi teaching his students in Europe would need to search a student for contraband. Today, American schools are frequently called "battle zones," with metal detectors reinforcing this epithet. This article contrasts searches of students and confiscation of their property from a historical Jewish legal (i.e., halachic) perspective and a contemporary United States legal perspective.

The need to create a safe and secure school is a prerequisite not easily attained. To what lengths may school officials go to achieve a favorable learning environment without sacrificing the legal rights of the very students being taught? What are the boundaries of school authorities and students' rights? The answers are found by juxtaposing complex and theoretical halachic decisions with American court decisions spawned by students carrying drugs and weapons to school.

It is not uncommon for teachers to confiscate items belonging to students. At times, this is done simply because the school has banned the item from its premises and mere possession is ipso facto a breach of school policy. The most obvious example is the policy of many schools with regard to weapons and drugs. At other times, the item may be confiscated as a disciplinary measure because the student has used it in an inappropriate manner, e.g., a student has used a ruler to slap another student, or simply because the student's preoccupation with the object causes the student to be inattentive.

Often, the confiscation is temporary and the item is returned when behavior improves, when the item will no longer cause disruption, or simply because temporary confiscation is deemed to be a sufficient punishment. Sometimes, seizure is designed to serve as punishment or deterrent and is permanent. In an educational setting, such acts are presumably designed for the benefit of the particular student or for students as a whole.

* Rabbi Moshe A. Bleich, MSW, works at the Boro Park Office of Jewish Board of Family and Children's Services, New York.

** Daniel Pollack, MSW, JD, is assistant professor at Wurzweiler School of Social Work and is adjunct professor at Benjamin Cardozo School of Law, Yeshiva University, New York. 


\section{JEWISH HISTORICAL SOURCES}

Jewish legal sources analyze various aspects of this issue. Writing in the Israeli annual Tehumin, VIII (1987), Rabbi Yehudah Herzl Henkin notes that the Gemara, Baba Metsi'a 61b, declares that the prohibition against theft applies even "al menat le-meikat," which Rashi, ad locum, defines as "letsayer," i.e., theft for the purpose of inflicting anguish or discomfort upon the victim. The Gemara declares that this prohibition applies even when the theft is committed "al menat le-shalem tashlumei kefel," i.e., the thief wishes to benefit the victim by becoming liable for a fine to be paid to the victim. In such cases, the thief intends no harm; on the contrary, he is motivated by a desire to enrich his "victim." In establishing a blanket prohibition, the Talmud clearly bans theft even when the theft redounds to the benefit of the victim. These provisions of Jewish law are recorded in Shulhan Arukh, Hoshen Mishpat 348:1.

The definition of "al menat le-meikat" (for the purpose of inflicting anguish) is a matter of dispute among early-day authorities. A collection of medieval talmudic commentaries, Shitah Mekubetset, Baba Metsi'a 61b, notes that some interpret "al menat le-meikat" as including the notion that the individual has no intention of retaining the object permanently, but intends only to deny the rightful owner use of his property for a limited period of time in order to cause him distress. However, Shitah Mekubetset, in rejecting that definition, apparently maintains that theft with intent to restore the stolen item to its rightful owner does not constitute a violation of the prohibition against theft and interprets "al menat le-meikat" as referring to theft of an object without intent to return. Theft "al menat le-meikat," according to Shitah Mekubetset, differs from ordinary theft only in motivation; the item is taken solely in order to cause pain to the victim and not because the thief desires any benefit from, or contemplates any use of, the stolen object. Two other early day commentators, Tosafot Rabbenu Perets and Ritva ha-Hadashim, Baba Metsi' $a$ 61b, also cite the latter interpretation of "al menat le-meikat" in the name of Rabbenu Tam. According to those authorities, there is no question that a school official might deprive a student of an object on a temporary basis without incurring a transgression.

A prominent nineteenth-century work, Ketsot ha-Hoshen 348:1 cites the comments of Maimonides in his Sefer ha-Mitsvot, negative commandments, no. 244 , and notes that Maimonides maintains that it is forbidden to steal even with intention to restore the property to the rightful owner. That is also the position of Sefer ha-Hinnukh, mitsvah 224. Ketsot ha-Hoshen concludes that although Shitah Mekubetset remarks that theft of objects on an interim basis is a common and, indeed, a daily occurrence, nevertheless, in light of Maimonides' restrictive position, it is appropriate to be careful not to seize another person's property even temporarily. Similarly, Rabbi Naftali Zevi Yehudah Berlin, Emek ha-She'elah, she'ilta 4, no. 6, maintains that the 
She 'iltot prohibits even temporary appropriation of an object belonging to another person.

Rabbi Henkin asserts that even those who maintain that one may steal an object temporarily permit such an act only if the object is retained for but a very brief period of time. Rabbi Henkin notes that Rabbenu Perets employs language stating that such an act is permitted only if the object is to be retained for only a "brief period" (i.e., le-sha'ah). Accordingly, Rabbi Henkin argues that if the teacher plans to return the object, but only after an indefinite period, the act is forbidden even according to Rabbenu Tam.

Rabbi Henkin further asserts that the connotation of "le-sha' $a h$ " is that the object must be returned in a matter of hours, possibly on the same day. Hence, argues Rabbi Henkin, if a teacher confiscates an item with the intention of returning it to the student the next day, all authorities would agree such an act is prohibited. Against that conclusion it may be argued that the term "le-sha'ah," employed by Rabbenu Perets, is idiomatic and is used in contrast to language signifying permanent retention of the stolen property but is not designed to establish an exclusion limited to custody of the object for merely a matter of hours. Thus, "le-sha' $a h$ " may be understood as connoting simply a temporary, rather than an indeterminately long, period of time. Furthermore, neither Ritva ha-Hadashim nor Shitah Mekubetset incorporates the phrase "le-sha'ah" in his comments. Moreover, it appears that both Ketsot ha-Hoshen and Torah Temimah, Leviticus 19:11, no. 60, understand Shita Mekubetset's position to be that taking possession of an object for even an indefinite period is permissible so long as there is no intent to retain the object permanently.

Rabbi Henkin does not note this, although Ketsot ha-Hoshen states that "it is proper to be watchful with regard to the matter" but does not pronounce an unequivocal ban. It is, nevertheless, the consensus of other latter-day authorities that the practice is prohibited. The Shulhan Arukh ha-Rav, Hilkhot Gezeilah u-Geneivah, no. 3, Kitsur Shulhan Arukh 182:3, and Arukh haShulhan, Hoshen Mishpat 348:3, as well as Torah Temimah, Leviticus 19:11, no. 60 , all rule that it is prohibited to appropriate an object for even a brief period. ${ }^{1}$

1. Liability for loss or damage of the object appropriated under such circumstances is also the subject of considerable discussion. An ordinary thief is responsible for all damages, including those suffered as a result of force majeure. Ketsot ha-Hoshen 348:1 expresses doubt with regard to whether or not there is an obligation to make restitution in the event that the object is damaged as a result of circumstances beyond the control of the "thief" (i.e., ones). See also Minhat Hinnukh, no. 224. Compare, however, Ketsot ha-Hoshen 291:2 where, citing Shitah Mekubetset, Baba Metsi'a 41a, Ketsot apparently maintains that a thief who steals al menat le-meikat is exempt from liability in cases of ones. Arukh ha-Shulhan 348:3 maintains that a person who steals al menat le-meikat is not liable for ones but must make restitution if the object is lost or stolen. On the other hand, Hazon Ish, Baba Kamma 20:5 and Torah Temimah, Leviticus 19:11, no. 60, maintain that liability is absolute. See also Rabbi Moshe 
Rabbi Henkin further suggests that there may be grounds to permit confiscation as a disciplinary measure in an educational setting since the intent of the teacher is not to inflict pain or distress upon the student but is rather intended for the student's benefit. In support of that distinction, he cites the comments of the early-day authority, Ritva, Baba Batra 5a. Ritva notes that the Gemara relates that a certain man named Runia owned a plot of land surrounded on all four sides by property belonging to Ravina. Ravina constructed a fence to separate his property from Runia's and demanded that Runia share in the expenses incurred in erecting the fence. Runia refused. Eventually, Ravina directed his servant to seize some of Runia's produce as compensation for labor and materials. Ritva questions the legitimacy of that action on the grounds that theft is prohibited even "al menat le-meikat" (i.e., for the purpose of inflicting pain). Ritva responds that seizure of someone else's property, not for the purpose of inflicting pain, but in order to satisfy an outstanding claim, is permissible. On that basis, Rabbi Henkin argues that the prohibition of theft "al menat le-meikat" is limited to theft with the specific intent to inflict pain; theft of a temporary nature that is motivated by other concerns is permissible.

It seems that Ritva's comments reflect an entirely different principle. Many authorities regard self-help as legitimate and appropriate in situations in which other forms of redress are not available. ${ }^{2}$ Ritva stresses that Ravina adopted this procedure "to execute his judgment." Moreover, as noted by Rabbi Henkin, on the basis of the comments of She 'iltot, She 'ilta 4, it is clear that She 'iltot maintains that, with regard to theft "al menat le-meikat," intent to cause distress is not a necessary condition, and the act is prohibited so long as the individual whose property is being seized experiences pain and distress.

Maimonides, Hilkhot Geneivah 1:2, unequivocally declares that all acts of theft are banned lest a person become habituated to such conduct:

It is biblically prohibited to steal even a minute amount. It is prohibited to steal in jest or to steal in order to return the object or in order to make restitution. Everything is prohibited so that a person not accustom himself with regard to this.

Aryeh Leib Shapiro, Tabe'ot Zahav 348:1 (2d ed., Jerusalem 1987) (a commentary on Ketsot ha-Hoshen), who argues against liability in case of ones. For a further discussion of this issue, see IV Pithei Hoshen 24, n.17.

2. See Hoshen Mishpat 4:1.

3. Compare, however, the comments of Sefer Hasidim no. 585 (Reuben Margulies ed., Jerusalem 1960), who apparently maintains that one may seize an object for a temporary period in order to benefit the person from whom the object is taken. See also Sedei Hemed, Pe'at ha-Sadeh, ma'arekhet ha-gimel, no. 5. 
Thus, Maimonides rules that all acts of theft are proscribed and allows no exception for salutary intent.

Nevertheless, one latter-day authority, Teshuvot Oneg Yom Tov, no. 48, permits theft with intent to restore the stolen object when such theft is undertaken for purposes of performing a mitsvah. A contemporary writer, Rabbi Ya'akov Yeshaya Blau, Pithei Hoshen, IV, 24, n.17, argues that, since a teacher's confiscation of a student's property for a disciplinary purpose is integral to the mitsvah of hinnukh (i.e., "teaching"), it is permissible for the teacher to act in that manner. Relying upon a combination of the view of Oneg Yom Tov and the earlier cited view of Shitah Mekubetset to the effect that theft with intent to retum is not prohibited, Rabbi Blau concludes that a student's property may be confiscated even for an indefinite period, provided that the teacher plans to return the object at some future time. Although Rabbi Blau cites Oneg Yom Tov's ruling as authoritative, the writers are unaware of other authorities who accept this view. It is apparently the consensus of the previously cited authorities, including Shulhan Arukh ha-Rav, Arukh haShulhan, and Kitsur Shulhan Arukh, that all forms of theft are prohibited, even if the theft is temporary in nature and even if committed for meritorious purposes.

\section{A. Rights and Obligations of Teachers}

Rabbi Henkin also advances an entirely different argument in justifying confiscation of students' property as a disciplinary measure. The Mishnah, Makkot $7 \mathrm{~b}$, rules that a father who unintentionally causes the death of a son, a teacher who causes the death of a student in the course of administering corporal punishment, and a court official who causes death in the course of administering lashes to a convicted transgressor are exempt from the penalty of exile since the death occurred in the course of performing a mitsvah (i.e., in the case of the father or teacher, the requirement of training children in the performance of the commandments). Rabbi Henkin cites scholars who argue that since a teacher is permitted to strike a student, he must similarly be permitted to appropriate his property. It should be noted that the editor of Tehumin quotes Rabbi Yehudah Shaviv as advancing precisely this argument, that just as a teacher is permitted to violate the prohibition of striking another person-as expressed in Deuteronomy 25:3-by striking a student, he is similarly permitted to violate other interpersonal prohibitions, and, hence, he may confiscate a student's property for pedagogical purposes.

As further noted by the editor of Tehumin, Rabbi Shlomo Min-Hahar, writing in Shm'attin nos. 46-47 (Tammuz 1976), has similarly argued that if a teacher is justified in inflicting corporal punishment and causing physical pain, it stands to reason that he may impose a temporary pecuniary burden 
upon a student in confiscating his property for an indefinite period of time. ${ }^{4}$ Rabbi Henkin, however, argues that although a teacher has the right to administer corporal punishment, a teacher has no authority to impose monetary penalties. He argues, in effect, that prohibitions are not suspended even in order to achieve laudable goals and that chastisement of a child or student is not at all encompassed within the ambit of the prohibition against striking one's fellow because that prohibition is limited to such conduct undertaken in the form of assault.

Rabbi Henkin fails to note that a similar point has been made by the twentieth-century scholar, Rabbi Elchanan Wasserman, in his Kovets He'arot, no. 70. Rabbi Wasserman cites the comments of Maimonides, Hilkhot Hovel $u$-Mazik $5: 1$, indicating that the prohibition against striking one's fellow is limited to striking him derekh nitsayon, i.e., in the nature of an assault. ${ }^{5}$ Indeed, Rabbi Wasserman points to a father's license to strike a son and a teacher's right to chastise a student as Rambam's source for this statement. ${ }^{6}$

Accordingly, Rabbi Henkin forcefully and convincingly concludes that it is prohibited for a teacher to confiscate property. However, he rules that it is permissible for a teacher to deprive the child of the use of an object by taking the object and placing it on the teacher's desk while indicating that the student may reclaim the object at the end of the class or at the end of the day. Rabbi Henkin does not present a clear explanation for this leniency. Presumably, he reasons that Jewish law stipulates that, in order to be guilty of an act of theft, one must make a "kinyan geneivah," i.e., perform an act of "acquisition." Such a kinyan entails unlawfully removing an object from the owner's domain. Rabbi Henkin apparently reasons that placing and retaining the object on the teacher's desk does constitute an act of "acquisition" with regard to the object and that no act of theft has taken place because the item

4. Surprisingly, Rabbi Min-Hahar maintains that confiscation of a student's property is permitted but that fining a student for inappropriate behavior is prohibited as an act of extortion or "theft." Rabbi Min-Hahar cites no sources to buttress his contention that temporary theft is not an act of theft; as demonstrated earlier, the consensus of halachic scholars is the reverse. It may be noted that Rabbi Min-Hahar's article is entirely polemical in nature and cites absolutely no primary or secondary sources that address the issue directly. It is rather surprising that the editor of Tehumin cites this article as carrying halachic weight. The concluding sentence of Rabbi Henkin's rebuttal to the editor, stating that the article in Shm 'attin does not add or detract from the discussion and is thus irrelevant, is entirely on the mark.

5. See also XII Encyclopedia Talmudit, Hovel 683 n.64. Cf. id. n.68. See also Rabbi Moses Feinstein, II Iggerot Mosheh, Hoshen Mishpat, no. 66.

6. It should also be noted that even if it might be demonstrated that a teacher has a right to confiscate property as a disciplinary measure, the authority to do so is certainly limited in nature. Rabbi Moshe Feinstein, II Iggerot Mosheh, Yoreh De'ah, no. 103, cogently argues that for a teacher to administer any form of discipline, it is not sufficient merely to have grounds for suspecting the student of a misdeed; rather, the teacher must have actual knowledge that the student has committed the misdeed for which he or she is being punished. 
in question remains in an area accessible to the student and in an area in which the student's proprietary rights are equal to those of the teacher.

\section{B. Dangerous Objects}

Confiscation of an object that poses a potential danger to its owner or to others is an entirely different matter. The Code of Jewish Law, Shulhan Arukh, Hoshen Mishpat 426:8, rules that failure to remove a dangerous object constitutes a violation of the commandments "[ $[\mathrm{t}] \mathrm{ake}$ heed to yourself and guard your life diligently" (Deuteronomy 4:9) and "you shall not bring blood upon your house" (Deuteronomy 22:8). A contemporary compendia, Pithei Hoshen, V, 37, n.12, indicates that quite apart from the need to train children in the obligations established by those commandments, the language employed by Shulhan Arukh suggests that the obligation to remove a dangerous object devolves not only upon the owner of the object but also upon the bystander. Shulhan Arukh 382:1 depicts the bystander who eliminates the danger as a person who "seizes a mitsvah" that is the prerogative of another. The clear implication is that, if it is clear that the owner has no intention of fulfilling the obligation, others are certainly at least permitted, and possibly obligated, to do so. The proper course of action for a teacher responsible for the safety of his or her charges is self-evident.

\section{CONTEMPORARY AMERICAN LAW}

In American law, temporary seizure of a student's property is rarely a criminal act. The law in New York, for example, is quite clear in its refusal to recognize temporary deprivation of use of property as an act of larceny. The Penal Law of New York defines larceny as theft "with intent to deprive another of property or to appropriate the same to himself or a third person."

In People v. Hoyt, ${ }^{8}$ the court held that to warrant a larceny conviction there must be intent to permanently deprive the owner of property. Temporary withholding of property, by itself, would not constitute larcenous intent. ${ }^{9}$ In People v. Ward, ${ }^{10}$ the court held that, at minimum, there must be intent to permanently deprive another person of property or to deprive the person of it "for so extended a period of time that a major portion of its economic value is lost." American courts have, however, dealt extensively with another form of discipline employed in public schools. These cases involve a single primary source of American law-the Fourth Amendment. 
The leading United States Supreme Court precedent, New Jersey $v$. T.L.O. ${ }^{11}$ amplifies an exception to the probable cause and warrant requirement for searches done by public school officials. In T.L.O., a teacher discovered fourteen-year-old T.L.O. smoking in the school bathroom. When T.L.O. was questioned by the vice-principal, T.L.O. said she did not smoke. The vice-principal demanded to search her purse. Discovered inside were rolling papers used to make marijuana cigarettes, marijuana, a pipe, a wad of one-dollar bills, a list containing names of students who may have owed her money, and two letters implicating her in dealing marijuana. The Supreme Court eventually upheld the reasonableness of the search. The Court held that "[ $t]$ he determination of the standard of reasonableness governing any specific class of searches requires 'balancing the need to search against the invasion which the search entails." 12

The Supreme Court sets out a two-prong test to establish whether a public school official has "reasonable suspicion" to conduct a search:

[F]irst, one must consider "whether the . . . action was justified at its inception," . . . second, one must determine whether the search as actually conducted "was reasonably related in scope to the circumstances which justified the interference in the first place[.]" Under ordinary circumstances, a search of a student by a teacher or other school official will be "justified at its inception" when there are reasonable grounds for suspecting that the search will turn up evidence that the student has violated or is violating either the law or the rules of the school. Such a search will be permissible in its scope when the measures adopted are reasonably related to the objectives of the search and not excessively intrusive in light of the age and sex of the student and the nature of the infraction. ${ }^{13}$

The Court balances "the substantial need of teachers and administrators for freedom to maintain order in the schools"14 against the privacy interests of students. While acknowledging that " $[\mathrm{m}]$ inors, as well as adults, are protected by the Constitution and possess constitutional rights[,]"15 it is "equally well settled that the fourth amendment's protection, which only applies to governmental action, applies to searches conducted by public school officials

11. 469 U.S. 325 (1985).

12. Id. at 337 (citing Camara v. Municipal Court, 387 U.S. 523, 536-37 (1967)).

13. Id. at 341-42 (footnotes omitted) (citing Terry v. Ohio, 392 U.S. 1, 20 (1968)).

14. Id. at 341 .

15. Planned Parenthood of Central Missouri v. Danforth, 428 U.S. 52, 74 (1976). 
who act as representatives of the state."16

Vigilance by school officials to create a safe school environment is complicated by the uncertain application of DeShaney $v$. Winnebago County Dep't of Soc. Services. ${ }^{17}$ Is there a "special relationship" between students and school officials such that harm to a student by a fellow student may create school liability? The courts are of a mixed opinion. ${ }^{18}$ Ironically, the finding of a "special relationship" may prompt school officials to engage in questionable searches of individual students in the interest of maintaining security for the greater student body.

The burgeoning problem of weapons and drugs has recently been confronted by American courts. ${ }^{19}$ One California Court of Appeal notes that the "gravity of the danger posed by possession of a firearm . . . was great compared to the relatively minor intrusion involved in investigating the veracity of the unidentified student's accusation."20 But, T.L.O. and its progeny should not be read too broadly. There are limits to the right to search. In People v. Dilworth, ${ }^{21}$ a full-time police officer assigned to a school improperly seized a flashlight containing cocaine from a student simply because the student was associating with another student reputedly involved in drug dealing. A suspicion based on a mere "hunch" cannot be equivalent to "reasonable suspicion." The fact that the official conducting the search was a police officer rather than a school official was critical. Law enforcement officers cannot arbitrarily invade the privacy rights of individuals. However, a security officer who heard a metallic sound when a student tossed his bookbag on a metal shelf was permitted to feel the outside of the bag, discern the shape of a gun, and open the bag to discover a handgun inside. ${ }^{22}$ There was no premonition of a gun inside the bag. Rather, there was some reasonable suspicion based on concrete evidence:

16. In re Doe, 887 P.2d 645, 649 (Haw. 1994) (citing New Jersey v. T.L.O., 469 U.S. $325,336(1985))$.

17. 489 U.S. 189 (1989).

18. See D.R. v. Middle Bucks Area Vocational Technical School, 972 F.2d 1364 (3d Cir. 1992) (en banc), cert. denied, 506 U.S. 1079 (1993); J.O. v. Alton Community Unit School District 11, 909 F.2d 267 (7th Cir. 1990); Pagano v. Massapequa Public Schools, 714 F. Supp. 641 (E.D.N.Y. 1989).

19. See In re Joseph G., 38 Cal. Rptr. 2d 902 (Cal. Ct. App. 1995); S.D. v. State of Florida, 650 So.2d 198 (Fla. Dist. Ct. App. 1995); Wilcher v. State, 876 S.W.2d 466 (Tex. App. 1994); ex rel. Doe, 887 P.2d 645 (Haw. 1994).

20. In re Alexander B., 220 Cal. App. 3d 1572, 1577 (Cal. Ct. App. 1990).

21. 640 N.E.2d 1009 (IIl. App. Ct. 1994).

22. In re Gregory M., 82 N.Y.2d 588 (1993). 
Because appellant's diminished expectation of privacy was so clearly outweighed by the governmental interest in interdicting the infusion of weapons ... we think the "unusual" metallic thud ... was sufficient justification for the investigative touching of the outside of the bag . ....

The court noted, too, that the search was conducted for the purpose of school security, not for a criminal investigation. However, even in a criminal investigation situation, a protective pat-down exception to the warrant requirement may authorize a limited search to determine whether a weapon is present.

The possible possession and use of a weapon by a student is an excellent example of exigent circumstances sufficient to necessitate an immediate search. "Probable cause exists where 'the facts and circumstances within [the officials'] knowledge and of which they had reasonably trustworthy information [are] sufficient in themselves to warrant a man of reasonable caution in the belief that' an offense has been or is being committed."24 When a school principal strip-searched a student in order to determine whether the student had stolen money from a teacher, this was excessively intrusive, even though, when the principal looked into the underpants of the student, the missing $\$ 100$ was there. ${ }^{25}$ The court ruled that the invasion of personal privacy, even with individualized suspicion, is not equatable with searching a student's locker or personal possessions. It added:

[E]valuating the nature of the suspected infraction strictly in terms of the danger it presents to other students, it does not begin to approach the threat posed by the possession of weapons or drugs. ${ }^{26}$

Based on reasonable suspicion, it is valid to search a particular student's jacket, ${ }^{27}$ or a particular student's purse, ${ }^{28}$ for drugs. But search warrants "are ordinarily required... where intrusions into the human body are concerned." 29

"Confiscation" can be used in its literal sense, i.e., taking an object from a person. At issue is also the concern about "taking" someone's dignity and self-respect. Therefore, when doing a strip search of a student to determine

23. Id. at 593-94.

24. Brinegar v. United States, 338 U.S. 160, 175-76 (1949).

25. State ex rel. Galford v. Mark Anthony B., 433 S.E.2d 41 (W. Va. 1993).

26. Id. at 49.

27. In re Ronnie H., 603 N.Y.S.2d 579 (App. Div. 1993).

28. In re Doe, 887 P.2d 645 (Haw. 1994).

29. Schmerber v. California, 384 U.S. 757, 770 (1966). 
whether weapons, drugs, or other contraband is being concealed, a school official needs to take into account the severity of humiliation as compared to the likelihood of finding contraband: "Subjecting a student to a nude search is more than just the mild inconvenience of a pocket search . ..."30 The trauma associated with a strip search is well recognized. "Therefore, as the intrusiveness of the search of a student intensifies, so too does the standard of Fourth Amendment reasonableness. What may constitute reasonable suspicion for a search of a locker or even a pocket or pocketbook may fall well short of reasonableness for a nude search."

\section{CONCLUSION}

Interestingly, search of a student's person or possessions does not pose a problem in Jewish Law. Although a student would be fully entitled to refuse to submit to such a search, the procedure itself does not violate any particular law. Jewish law does indeed recognize a number of particular rights of privacy, e.g., the right to be free of even innocent voyeurism, respect of confidences, and the privacy of correspondence. Jewish Law does not posit a global right of privacy per se, nor does it define unwanted tactile contact as a battery. Hence, despite the fact that, in the absence of a pedagogic need, such practices are certainly not in conformity with the spirit of Jewish teaching, within an educational framework, justified searches may readily be carried out without incurring any technical violation.

There are strong halachic grounds to prohibit confiscation of a student's property as a general disciplinary measure. Nevertheless, there is some halachic support for such action. Apart from halachic considerations, such policies are contraindicated on pedagogical grounds firmly rooted in Jewish teaching. Maimonides, Hilkhot Geneivah 1:2, notes that the rationale underlying the prohibition against stealing in jest or with the intent to return the object is a need to prevent habituation to acts of theft. ${ }^{32}$ Teachers serve as role models for students. Confiscation of property by a teacher or an authority figure conveys a strong message; it diminishes respect for the property rights of others and teaches that appropriating someone else's property is not always wrong. Youngsters often do not fully comprehend nuances of the exceptions that prove the rule. The student may readily become "accustomed," or

30. Doe v. Renfrow, 475 F. Supp. 1012, 1024 (N.D. Ind. 1979).

31. Cornfield v. Consolidated High School District No. 230, 991 F.2d 1316, 1321 (7th Cir. 1993).

32. See also the comments of Minhat Hinnukh, no. 224, stressing that theft al menat lemeikat (for the purpose of inflicting anguish) is prohibited primarily because of its insidious effect upon the perpetrator. 
desensitized, to the severity of the prohibition against theft..$^{33}$

It is evident that, while traditional halachic sources focus on confiscation of student property for mild disciplinary purposes, contemporary American courts are confronted with serious security concerns. The respective judicial discussions indicate the stark contrast in school environments faced by teachers in historical time and today. The distinction between government and private oversight is also apparent. Rabbis were not representatives of the State. Rather, they were legitimate parental surrogates who could, for all practical purposes and if need be, claim a healthy dose of immunity. The balancing of interests in the form of "rights" that exists today in American law is absent in Jewish law.

Finally, an important distinction to make is the weight and legitimacy of the primary sources themselves: the United States Constitution and the Bible. "'We must never forget, that it is a constitution we are expounding', 'a constitution intended to endure for ages to come, and, consequently, to be adapted to the various crises of human affairs'. ${ }^{\prime 34}$ As highly regarded as is the U.S. Constitution (which can be amended), how much more so the Bible which allows for no amendment and whose source is divine rather than human!

33. A similar point in a somewhat different context is made by Iggerot Mosheh, Yoreh De'ah, II, no. 103.

34. Hirabayashi v. United States, 320 U.S. 81, 100-01 (1943) (emphasis added) (citing McCulloch v. Maryland, 17 U.S. (4 Wheat.) 316, 407, 415 (1819)). 